\title{
Non Market Effects of Education on Crime: Evidence from Italian Regions
}

\author{
Paolo Buonanno* \\ University of Bergamo \\ Leone Leonida ${ }^{\dagger}$ \\ Queen Mary University of London
}

\begin{abstract}
This paper studies the non market effects of education on crime using a panel dataset for the 20 Italian regions over the period 1980-1995. Our empirical results suggest that education reduces crime over and above its effect through labour market opportunities (employment rate and wage rate). Because of the absence of a credible instrumental variable for education for Italy, our empirical strategy is to include in our econometric specification region fixed-effect, year fixed effects and region-specific time trends together with an extensive set of socioeconomic and deterrence variables. Our results are robust to model specification, changes in the typology of crimes and finally, to alternative definitions of education.
\end{abstract}

Key words: Crime; Education; Labour market opportunities; Panel data.

JEL Classification: I2; J24; K42.

\footnotetext{
* Corresponding Author. Address: Dipartimento di Scienze Economiche, Università degli Studi di Bergamo, Via dei Caniana 2, 24127 Bergamo, Italy.Email: paolo.buonanno@unibg.it. We are particularly indebted to Piergiovanna Natale and an anonymous referee that greatly improved the paper. We are grateful to Luca Stanca, the participants of the seminars in Bergamo, Milan and Madrid for their useful advice and comments. Financial support from the University of Milan-Bicocca is gratefully acknowledged.

${ }^{\dagger}$ Department of Economics, Queen Mary University of London, Mile End Road, London E1 4NS, United Kingdom.
} 


\section{Introduction}

Does education reduce crime rate? Simple statistics, coupled with the empirical evidence, suggests that criminals tend to be less educated and from poorer and more disadvantaged backgrounds than non criminals. In 2001 more than $75 \%$ of the overall convicted population in Italy had not graduated from high school and, analogously, in the US two-thirds of the incarcerated men had not attained this level of education (Freeman, 1996).

Despite this evidence, few papers have studied the relationship between education and crime. Recently, Lochner (2004) and Lochner and Moretti (2004) find a significant and robust inverse relationship between crime and high school graduation.

The purpose of this paper is to study whether education affects crime rates over and above its effects trough market returns. Education may affect the decision to engage in criminal activities through several channels. First, higher levels of schooling are associated with higher wages, increasing the opportunity cost of criminal behaviour. Second, education may alter personal preferences so to affect decisions to engage in crime. In particular, Fajnzylber et al. (2002) suggest that, by incorporating a civic component, education may affect the individuals' perception of crime. Similarly, Usher (1997) stresses that education has a "civilization" effect beyond its market effect. Third, independently of the level of schooling, school attendance alone, reduces the time available for participating in criminal activities (Witte and Tauchen, 1994).

We identify some of these channels by using a simple dynamic model of individual choice, and test a number of these hypothesis using a panel dataset for the Italian regions, covering the period 1980-95. ${ }^{1}$

\footnotetext{
${ }^{1}$ Clearly, the use of individual data would be ideal to study the relationship between education and crime, since these datasets usually provide a large number of controls related to socioeconomic and sociodemographic variables.
} 
The key empirical difficulty in estimating the relationship between education and crime is the possible presence of unobserved characteristics and factors affecting both schooling and crime decisions. For this reason, care must be given to the particular identification strategy one uses.

For instance, Lochner and Moretti (2004) use changes in compulsory schooling laws over time as an instrument for education. In the absence of a credible instrumental variable for education in the Italian case, and in order to mitigate omitted-variables bias, we take a large number of precautions. First, we exploit the panel aspects of our data by estimating models allowing for region fixed effects, year effects and region-specific linear and quadratic time trends (Raphael and Winter-Ebmer, 2001). In these models, the trend is included to capture all trending (but omitted) variables that can influence crime rates; therefore, identification comes from nonlinear deviations of education from the time trend.

Second, we control extensively for observable socio-economic and deterrence variables, such as labour market opportunities (wage and employment rate), GDP per capita, GDP growth rate, police forces, quickness of conclusion of judicial proceedings and percentage of crime committed by unknown offenders.

Third, we adopt different measures of education. This allows us to test the fact that crime rate could depend more on variation in high school graduation rates than college graduation rates; as shown by statistics on convicted population presented above, marginal criminals tend to be high school drop outs.

Fourth, we study the correlation between education and, separately, property crime, theft and total crime, which allows us to avoid aggregation bias (Cherry and List, 2002).

Unfortunately, individual panel data for Italy are not available and then the use of regional panel data represents the "second best" methodological option. 
Finally, in an attempt to account for inertial effects of crime we propose a dynamic panel data model, estimated by means of the GMM-system estimator.

Our findings suggest that education is negatively and significantly related to crime rates even after controlling for labour market opportunities. Results show that crime rate displays persistence over time. Interestingly, high school graduation rate is significantly and negatively correlated to crime rates, while college graduation rate seems to not exert a significant effect.

The paper proceeds as follows. Section reviews 2 previous studies. Section 3 describes our dataset and discusses some empirical issues. Empirical results are presented in Section 4. Section 5 , finally, concludes.

\section{Previous Studies}

The idea that education may have a negative effect on crime through its effect on wages is not a new one. Theory suggests several channels through which schooling may affect criminal behaviour. Most of these contributions stress how education raises individuals' skills and abilities, thus increases the returns from legitimate work, raising the opportunity costs of illegal behaviour. But there exist benefits from education that are not taken into account by individuals; this implies that the social return of education is higher than its private return (Lochner and Moretti, 2004).

Lochner (2004) explores the relationship between education and crime within the standard Becker (1964) and Ben-Porath (1967) investment model of human capital formation. Using micro data from the NLSY Lochner finds a strong negative effect of education both on unskilled property crime and violent crime. Similarly, Lochner and Moretti (2004) using three different data sources (Census, Uniform Crime Reports and NYLS79) confirm that education significantly reduces criminal activity. 
A different approach is followed by Usher (1997). He suggests that education may also have a "civilization" effect beyond its market effect. Education conveys a civic externality, a benefit to society over and above the benefit to the student in enhancing his future earning power. The civic externality is incorporated into an "anarchy" model where people choose to be farmers or bandits, and schooling inculcates distaste for a life of crime. Furthermore, Witte and Tauchen (1994) suggest that school enrolment alone, independently of the level of schooling, reducing the time available for participating in the crime activity leads to a reduction in the crime rate.

\section{Data and Empirical Metodology}

\subsection{Data}

Our panel dataset comprises annuals observations for the 20 Italian regions (NUTS2) ${ }^{2}$ over the period 1980 to $1995 .^{3}$ Table 1 presents summary statistics. Crime data are taken from CRENoS (Centre for North South Economic Research). In particular, we consider three different crime rates (Crime): property crime, theft and total crime. The crime rate is obtained normalizing the total number of crime in each category by resident population in each region, population is taken from ISTAT. The explanatory variables are separated into three groups: education, deterrence variables and socioeconomic variables.

We use different measures of education: percentage of population with high school diploma (High School), percentage of population with university degree (University) and average years of schooling of the population (Avg Years School). High School and University are taken from Quarterly Labour Forces by ISTAT, while Avg Years School is our own calculation from

\footnotetext{
${ }^{2}$ Valle d'Aosta has been aggregated to Piemonte due to its small dimensions.

${ }^{3}$ We use data from 1980 to 1995 when discontinuity arose following the adoption of a new classification system (SECS95). Moreover, police data at regional level are available until 1996.
} 
Quarterly Labour Forces. The variable Enrolment, taken from ISTAT, is defined as the ratio between students enrolled in high-school and university and the total population of each region.

We use four deterrence variables: quickness of conclusion of Istruttoria and Primo Grado (Istruttoria) and Appello and Cassazione (Appello) measured as inverse of average length of judicial process, ${ }^{4}$ percentage of crimes committed by unknown offenders (Unknown) as proxy of the probability of apprehension, measured as the ratio of crimes committed by unknown offenders to all recorded crimes in each category and, finally, the extent of police forces (Police), normalized by population. ${ }^{5}$ All these four variables are taken from CRENoS.

We complete the dataset by adding a set of socioeconomic variables taken from ISTAT. In particular, the employment rate (Employment), the average regional wage (Wage) at 1990 constant price, GDP per capita $(G D P)$ at 1990 constant prices and the growth rate in GDP (Growth). Employment and Wage capture the labour market opportunities of the region that, as shown in our theoretical model, may represent two important determinants of crime behaviour. Following Ehrlich (1973) we can consider the GDP and Growth as proxies for the general level of prosperity in the provinces, thus as indicators of illegal income opportunities.

\subsection{The empirical procedure and the econometric issues}

The key empirical difficulty in estimating the effect of education on crime is the presence of unobserved factors affecting both schooling decisions and criminal behaviour. More generally, estimated coefficients may be biased upward, leading us to overestimate the effect of schooling.

To address unobserved heterogeneity problems, the best option would be to use a credible instrumental variable for education. In the absence of such an instrument for the Italian case (i.e.

\footnotetext{
${ }^{4}$ Istruttoria and Primo grado represents the first stage of the entire judicial proceeding. Appello and Cassazione represent respectively the second and the final stage of judicial proceeding.

${ }^{5}$ Italian police force is composed by Carabinieri, Polizia and Guardia di Finanza. All these three bodies of the Italian police force operate at national level.
} 
change in compulsory schooling laws), as previously discussed, we extensively control for socioeconomic and deterrence variables and exploit the panel structure of our dataset to net out variation in crime rates due to unobserved factors. Following Raphael and Winter-Ebmer (2001), we include region fixed effects to control for variation in crime rates determined by characteristics that vary across regions but are constant over time. Moreover, we include time year effects in order to adjust for the effect of factors that cause yearly changes in crime rates that are common to all regions. Finally, we add to our econometric specification both linear and quadratic region-specific time trends to control for variation in within-region crime rates due to factors that are region specific over time. In our model, the education-crime effect is identified using within-region variation in the education measure (relative to the national rate) after netting out region-specific time trends. Such a flexible specification should control for the influence of many unobserved factors.

Therefore, our most complete econometric specification is:

$$
\text { (1) } \text { Crime }_{i, t}=\alpha_{i}+\beta_{1} E_{d u_{i, t}}+\beta_{2} X_{i, t}+\tau_{t}+\delta_{i} \text { time }_{t}+\gamma_{i} \text { time }_{t}^{2}+\varepsilon_{i, t}
$$

where the subscripts $i$ and $t$ represent region and time period, respectively; $\alpha_{i}$ is a region fixed effect, $\tau_{t}$ is a time fixed effect, Crime $_{i, t}$ is the crime rate, $E d u_{i, t}$ is the education measure (as defined in the data section), $X_{i, t}$ is the set of explanatory variables as previously defined, time $_{t}$ and time $_{t}{ }_{t}$ are linear and quadratic region-specific time trends and $\varepsilon_{i, t}$ is the residual.

\section{Discussion of results}

\subsection{Main Results}

Our basic fixed effects estimates, that do not include linear and quadratic region-specific trend, are shown in Table 2. 
Our findings suggest that education has a negative effect on crime rate over and above its effect through labour market returns. Both High School and Avg Years School are negatively and significantly correlated to crime rates even after controlling for labour market opportunities. As regard to the additional regressors, GDP and Enrolment show significant coefficients with expected signs for every classification of crime rate. Furthermore, Unknown is positively and significantly correlated both to property and total crimes.

The results presented so far suggest that education exerts an effect on the three categories of crimes used. However, in order to account for unobserved factors linear and quadratic regionspecific trends are added to our baseline specification.

The results, presented in Table 3, indicate that the size of the coefficient on education measure decreases when linear and quadratic region-specific trends are included. These estimates are in line with our previous results, with the exception of total crime rate.

It is worth to notice that crime rate is negatively correlated to High School, while it is not significantly correlated to University. The intuition behind this result is that, in equilibrium, marginal criminals tend to be high school drop outs, not college graduate. Our findings are in line with Lochner and Moretti (2004) that find that the effect of high school graduation is larger than the effect of an additional year of school.

The econometric estimates corroborate the predictions of our theoretical framework. Education - both measured by High School and Avg Years School - exerts a negative and significant effect on property crime, theft and total crime rate even after controlling for socioeconomic variables and in particular for labour market returns and opportunities. Finally, 
Enrolment has a negative effect on crime rates, giving support to the incapacitation role of school attendance (Witte and Tauchen, 1994). ${ }^{6}$

\subsection{Accounting for Crime Dynamics}

Finally, we consider dynamics in delinquency. Previous works strongly suggest the possibility of criminal hysteresis or inertia (Sah, 1991; Glaeser et al., 1996; Fajnzylber et al., 2002); in other words, higher crime today is associated with higher crime tomorrow (i.e. persistence over time).

In an attempt to account for inertial effects of crime, we propose a dynamic panel data econometric model:

(3) Crime $_{i, t}=\alpha_{i}+\beta_{1}$ Crime $_{i, t-1}+\beta_{2} E d u_{i, t}+\beta_{3} X_{i, t}+\tau_{t}+\varepsilon_{i, t}$

To estimate equation (3) we employ the GMM-system estimator. For a detailed discussion about the econometric methodology employed in this section, we refer to Appendix D of Fajnzylber et al. (2002).

The GMM estimates, presented in Table 4, corroborate our previous results, suggesting that endogeneity of education does not seem to bias estimates of the effect of education on crime (Lochner, 2004).

Both High School and Avg Years School show a negative effect on property crimes and thefts. Lagged dependent variable, GDP and Unknown have significant coefficients with the expected signs for both property crimes and thefts. Crime rates display persistence over time. In particular, total crime rate show a bigger degree of inertia compared to property crime rate and thefts rate.

\footnotetext{
${ }^{6}$ Moreover, we study to what extent the presence of organized crime in some of the Italian regions may affect the results obtained in this section, given that it still constitutes a heavy deterrent both for investment and endogenous development. There exist several differences once we account for organized crime. In particular, High School displays a positive and significant effect on crime rates in the four regions considered than in the rest of Italy. Our analysis suggests that organized crime may affect crime rates, but we are unable to separate the effect of criminal organizations from other unobserved characteristics specific to the four regions considered.
} 
Wage and Employment are negatively and significantly associated to crime rate, even if their significance depends on the measure of education used. Deterrence variable (Police, Primo Grado and Appello) are not statistically significant.

With regards to the GMM specification tests both the Sargan and the second-order autocorrelation statistics support the correct specification of our econometric model. Finally, time dummies are jointly significant in all the models estimated.

\section{Concluding Remarks}

In this paper, we study whether education exerts a non-market effect on crime rate. For our empirical analysis we use a panel dataset for the Italian regions over the period 1980 to 1995. Given that a credible instrumental variable is not available for Italy (i.e. change in compulsory schooling laws) we include region fixed effects, year effects and linear and quadratic regionspecific trend to net out variation in crime rates due to unobserved factors. This approach partially allows us to tackle the fact that education is not likely to be exogenous, but one should be cautious in interpreting our findings in a causal way. Our empirical results indicate that education exerts a negative significant effect on crime rates after controlling for socioeconomic and deterrence factors. Both the share of population with a high school diploma and the average years of schooling of the population are negatively and significantly correlated to every classification of crime rate. Moreover, in line with previous results and simple statistics, we find that crime rate depend more on high school graduation rate than college graduation rate giving support to the intuition that marginal criminals are high school drop out or high school graduates, not college graduates.

Our findings suggest that education has a negative effect on crime rate over and above its effect through labour market returns. 


\section{References}

Becker G.S. (1968). Crime and Punishment: An Economic Approach. Journal of Political Economy 76 (2), 169-217.

Case, A.C., \& Katz, L.F. (1991). The Company You Keep: The effects of family and neighborhood on disadvantaged youth. NBER Working Paper no. 3705.

Cherry, T.L., \& List, J.A. (2002). Aggregation bias in the economic model of crime. Economics Letters 75 (1), 81-86.

Ehrlich, I. (1973). Participation in illegitimate activities: a theoretical and empirical investigation. Journal of Political Economy 81 (3), 521-565.

Fajnzylber, P., Lederman, D. \& N. Loayza (2002). Inequality and violent crime. Journal of Law and Economics 45 (1), 1-40.

Freeman, R.B. (1996). Why Do So Many Young American Men Commit Crimes and What Might We Do About It?. Journal of Economic Perspectives 10 (1), 25-42.

Glaeser, E.L., Sacerdote, B. \& J.A. Scheinkman (1996). Crime and social interactions. Quarterly Journal of Economics 111 (2), 507-548.

Grogger, J. (1995). The effect of arrest on the employment and earnings of young men. Quarterly Journal of Economics 110 (1), 51-72.

Lochner, L. (2004). Education, work and crime: a human capital approach. International Economic Review 45 (3), 811-843.

Lochner, L., \& Moretti, E. (2004). The effect of education on crime: evidence from prison inmates, arrests, and self-reports. American Economic Review 94 (1), 155-189.

Ludwig J., Duncan G.J. \& P. Hirschfield (2001). Urban Poverty and Juvenile Crime: Evidence from a Randomized Housing-Mobility Experiment. Quarterly Journal of Economics 116 (2), 655-680.

Raphael, S., \& Winter-Ebmer, R. (2001). Identifying the effect of unemployment on crime. Journal of Law and Economics 44 (1), 259-283.

Sah, R.K. (1991). Social Osmosis and Patterns of Crime. Journal of Political Economy 99 (6), 1271-1295.

Usher, D. (1997). Education as Deterrent to Crime. Canadian Journal of Economics 30 (2), 367384.

Witte, A.D., \& Tauchen, H. (1994). Work and crime: an exploration using panel data. Public Finance 49, 155-167. 


\section{Appendix A: A Simple Model of Education and Crime}

Consider a representative economy where individuals decide how to allocate their available time each period to education, crime and work in the legal sector with the aim of maximizing their expected disposable income. Individuals are endowed with an initial level of ability $h_{0}$, that represents the level of ability acquired during primary school, and learning ability $\varepsilon$. Denote level of ability at time t by $h_{t}=h\left(s_{t-1}, \varepsilon\right)$, time spent for education, $s_{t}$, and time for committing crime $d_{t}$. Total time each period is normalized to 1 , so time spent working is $l_{t}=1-s_{t}-d_{t}$. Each period individuals earn $w_{t} h_{t} l_{t}$ from legal work, where $w_{t}$ is the wage rate. If an individual is engaged in criminal activity, she obtains with probability $\left(1-\pi_{a}\right)$ a return $R\left(d_{t}, h_{t}\right)$, function of the time devoted to crime activities and individual ability.

Returns from crime are assumed to be strictly increasing and concave in $d_{t}$ and non decreasing in $h_{t}$. With probability $\pi_{a}$ a criminal is apprehended and punished. An apprehended criminal goes to jail for the entire period in which she is apprehended ${ }^{7}$ and received a punishment $P\left(d_{t}\right)$ increasing in $d_{t}$.

The individual's maximization problem is:

(a1) $\quad \max _{s . d} \sum_{t=1}^{T} \beta^{t} y_{t}$

under time constraints $l_{t}+s_{t}+d_{t}=1, l_{t}, s_{t}, d_{t} \geq 0$, where $\beta$ is the intertemporal discount rate.

Total disposable income is defined as follows

(a2) $\quad y_{t}= \begin{cases}w_{t} h_{t} t_{t}+R\left(d_{t}, h_{t}\right) & \text { with prob }\left(1-\pi_{\mathrm{a}}\right) \\ \bar{c}-P\left(d_{t}\right) & \text { with prob } \pi_{\mathrm{a}}\end{cases}$

\footnotetext{
${ }^{7}$ Our analysis is general and will not change allowing that an apprehended criminal goes to jail for a fraction of her disposable time.
} 
where $\bar{c}$ is the level of consumption of a convicted criminal. For simplicity we consider the case in which $\mathrm{T}=2$ and $s_{2}=0 .{ }^{8}$ Thus, we can rewrite the maximization problem in the following way:

$$
\max _{s_{1}, d_{1}, d_{2}}\left\{\begin{array}{l}
\left(1-\pi_{\mathrm{a}}\right) w_{1} h_{1}\left(1-s_{1}-d_{1}\right)+\left(1-\pi_{\mathrm{a}}\right) R\left(d_{1}, h_{1}\right)+\pi_{\mathrm{a}} \bar{c}-\pi_{\mathrm{a}} P\left(d_{1}\right) \\
+\beta\left[\left(1-\pi_{\mathrm{a}}\right) w_{2} h_{2}\left(1-d_{2}\right)+\left(1-\pi_{\mathrm{a}}\right) R\left(d_{2}, h_{2}\right)+\pi_{\mathrm{a}} \bar{c}-\pi_{\mathrm{a}} P\left(d_{2}\right)\right]
\end{array}\right\}
$$

The first order conditions with respect to $s_{1}, d_{1}$ and $d_{2}$ for an interior solution are:

$$
\begin{aligned}
& d_{1}:\left(1-\pi_{\mathrm{a}}\right) w_{1} h_{1}=\left(1-\pi_{\mathrm{a}}\right) R^{\prime}\left(d_{1}, h_{1}\right)-\pi_{\mathrm{a}} P^{\prime}\left(d_{1}\right) \\
& s_{1}:\left(1-\pi_{\mathrm{a}}\right) w_{1} h_{1}=\beta\left[\left(1-\pi_{\mathrm{a}}\right) w_{2} h_{2}^{\prime}\left(1-d_{2}\right)+\left(1-\pi_{\mathrm{a}}\right) R^{\prime}\left(d_{2}, h_{2}\right) h_{2}^{\prime}\right] \\
& d_{2}:\left(1-\pi_{\mathrm{a}}\right) w_{2} h_{2}=\left(1-\pi_{\mathrm{a}}\right) R^{\prime}\left(d_{2}, h_{2}\right)-\pi_{\mathrm{a}} P^{\prime}\left(d_{2}\right)
\end{aligned}
$$

Equations (a4) and (a6) suggest two channels through which education can affect criminal decisions. First, education increases individual returns from work, thereby increasing the opportunity costs of crime. ${ }^{9}$ Second, education affects the net marginal returns to crime. Equation (a5) allows us to study the costs and returns of education. On the one hand, a higher education implies higher returns both from work and crime; on the other hand, an individual with a high level of education if apprehended and convicted experiences a greater earnings loss. Thus, more time invested in education in the first period is associated with higher expected returns in the legal sector in the second period, this corresponds to a higher opportunity cost of crime and then to a lower level of crime in the second period. Hence, the first testable prediction of our model is that higher level of education is correlated to less crime.

Moreover, our model suggests that the higher the fraction of time spent committing crimes in $t=1$, the higher the fraction of time committing crime in $t=2$. A higher level of time spent

\footnotetext{
${ }^{8}$ Individuals in the second period do not invest in education due that they live the last period of their life.
} 
committing crimes in the first period implies less time dedicated to schooling in the same period. This reduces expected returns in the legal sector in $t=2$, which, in turn, lower the opportunity cost of committing crime in $t=2$. In this sense, our model predicts criminal inertia, which is the second testable hypothesis of our model.

Our theoretical model has other testable implications. It allows us to study the effect of wage on crime. However, we need to distinguish between first and second period. An increase of wage in the first period implies that education and crime are more costly in terms of foregone income, by choosing less education individuals will have a lower wage in the second period, and then the level of crime will be higher being the opportunity cost of crime lower. On the other hand, a higher wage in the second period reduces unambiguously time spent in crime in $t=2$. Finally, prevention and effective law enforcement policies reduce crime rate: an increase in the probability of apprehension $\left(\pi_{a}\right)$ corresponds to a reduction of the expected return from illegal activities, and this leads to a reduction in the level of time spent in committing crime.

\footnotetext{
${ }^{9}$ As long as education increases the marginal return to work more than crime $w_{t} h_{t}^{\prime}\left(s_{t-1}\right)>R_{h t} h_{t}^{\prime}\left(s_{t-1}\right)$, crime is decreasing in education. We argue that, for unskilled property crimes, education is likely to have a little effect on their returns.
} 


\begin{tabular}{lcccc}
\hline \hline & Mean & Std. Dev. & Min & Max \\
& & & & \\
\cline { 2 - 5 } & & & & \\
High School & 14.77 & 3.95 & 7.60 & 26.29 \\
University & 3.11 & 0.95 & 1.50 & 7.04 \\
Average years of schooling & 6.19 & 0.85 & 4.29 & 8.17 \\
Enrolment rate & 4.68 & 0.57 & 3.51 & 6.44 \\
GDP per capita & 20.33 & 5.34 & 11.01 & 31.37 \\
Employment & 39.72 & 5.92 & 28.64 & 51.80 \\
Wage & 16.54 & 1.95 & 11.89 & 22.36 \\
Growth rate & 1.90 & 2.51 & -7.20 & 14.47 \\
Total crime & 35.19 & 16.20 & 13.74 & 115.56 \\
Total unknown & 70.70 & 10.86 & 33.91 & 93.93 \\
Property crime & 24.93 & 13.21 & 6.22 & 98.00 \\
Property unknown & 91.25 & 4.17 & 75.42 & 99.09 \\
Theft & 21.44 & 11.66 & 4.52 & 80.32 \\
Theft unknown & 95.49 & 2.42 & 80.50 & 99.34 \\
Police force & 4.37 & 1.83 & 1.13 & 9.72 \\
\hline \hline
\end{tabular}


Table 2: Fixed Effects

\begin{tabular}{|c|c|c|c|c|c|c|}
\hline & \multicolumn{2}{|c|}{ PROPERTY CRIMES } & \multicolumn{2}{|c|}{ THEFTS } & \multicolumn{2}{|c|}{ TOTAL CRIMES } \\
\hline & (a) & (b) & (a) & (b) & (a) & (b) \\
\hline High School & $\begin{array}{c}-0.1261 \\
(0.049)^{* *}\end{array}$ & & $\begin{array}{c}-0.0885 \\
(0.045)^{* *}\end{array}$ & & $\begin{array}{l}-0.1299 \\
(0.074)^{*}\end{array}$ & \\
\hline University & $\begin{array}{l}0.0905 \\
(0.308)\end{array}$ & & $\begin{array}{c}-0.0215 \\
(0.258)\end{array}$ & & $\begin{array}{l}0.3168 \\
(0.463)\end{array}$ & \\
\hline Avg School Years & & $\begin{array}{l}-0.0114 \\
(0.005)^{* *}\end{array}$ & & $\begin{array}{l}-0.0105 \\
(0.005)^{* *}\end{array}$ & & $\begin{array}{l}-0.0104 \\
(0.006)^{*}\end{array}$ \\
\hline Enrolment & $\begin{array}{l}-0.8563 \\
(0.329)^{* *}\end{array}$ & $\begin{array}{l}-0.7256 \\
(0.312)^{* *}\end{array}$ & $\begin{array}{l}-0.6733 \\
(0.276)^{* *}\end{array}$ & $\begin{array}{c}-0.5397 \\
(0.246)^{* *}\end{array}$ & $\begin{array}{c}-0.9893 \\
(0.397)^{* *}\end{array}$ & $\begin{array}{l}-0.9481 \\
(0.439)^{* *}\end{array}$ \\
\hline Employment & $\begin{array}{l}0.0235 \\
(0.046)\end{array}$ & $\begin{array}{l}0.0227 \\
(0.052)\end{array}$ & $\begin{array}{l}0.0197 \\
(0.037)\end{array}$ & $\begin{array}{l}0.0203 \\
(0.040)\end{array}$ & $\begin{array}{l}0.0250 \\
(0.072)\end{array}$ & $\begin{array}{l}0.0287 \\
(0.077)\end{array}$ \\
\hline Gdp per capita & $\begin{array}{c}0.0018 \\
(0.0006)^{* * *}\end{array}$ & $\begin{array}{c}0.0015 \\
(0.0007)^{* *}\end{array}$ & $\begin{array}{c}0.0016 \\
(0.0006)^{* * *}\end{array}$ & $\begin{array}{c}0.0015 \\
(0.0006)^{* *}\end{array}$ & $\begin{array}{c}0.0026 \\
(0.0009)^{* * *}\end{array}$ & $\begin{array}{c}0.0024 \\
(0.0009)^{* *}\end{array}$ \\
\hline Growth rate & $\begin{array}{c}-0.0010 \\
(0.009)\end{array}$ & $\begin{array}{l}0.0014 \\
(0.010)\end{array}$ & $\begin{array}{c}-0.0009 \\
(0.008)\end{array}$ & $\begin{array}{l}0.0008 \\
(0.009)\end{array}$ & $\begin{array}{c}-0.0019 \\
(0.013)\end{array}$ & $\begin{array}{c}-0.0008 \\
(0.015)\end{array}$ \\
\hline Wage & $\begin{array}{c}-0.0022 \\
(0.001)\end{array}$ & $\begin{array}{l}-0.0025 \\
(0.001)^{*}\end{array}$ & $\begin{array}{c}-0.0015 \\
(0.001)\end{array}$ & $\begin{array}{l}-0.0018 \\
(0.001)^{*}\end{array}$ & $\begin{array}{c}-0.0026 \\
(0.002)\end{array}$ & $\begin{array}{l}-0.0033 \\
(0.002)^{*}\end{array}$ \\
\hline Unknown & $\begin{array}{c}0.0403 \\
(0.020)^{* *}\end{array}$ & $\begin{array}{c}0.0396 \\
(0.023)^{*}\end{array}$ & $\begin{array}{l}0.0261 \\
(0.020)\end{array}$ & $\begin{array}{l}0.0306 \\
(0.024)\end{array}$ & $\begin{array}{c}-0.0079 \\
(0.020)\end{array}$ & $\begin{array}{c}-0.0078 \\
(0.022)\end{array}$ \\
\hline Police & $\begin{array}{c}1.709 \\
(1.243)\end{array}$ & $\begin{array}{c}1.708 \\
(1.323)\end{array}$ & $\begin{array}{c}1.362 \\
(1.046)\end{array}$ & $\begin{array}{c}1.374 \\
(1.096)\end{array}$ & $\begin{array}{c}2.990 \\
(1.725)^{*}\end{array}$ & $\begin{array}{c}3.021 \\
(1.849)^{*}\end{array}$ \\
\hline Primo Grado & $\begin{array}{l}0.2821 \\
(0.303)\end{array}$ & $\begin{array}{l}0.2496 \\
(0.336)\end{array}$ & $\begin{array}{l}0.2433 \\
(0.240)\end{array}$ & $\begin{array}{l}0.2088 \\
(0.479)\end{array}$ & $\begin{array}{l}0.4755 \\
(0.419)\end{array}$ & $\begin{array}{l}0.4788 \\
(0.465)\end{array}$ \\
\hline Appello & $\begin{array}{c}-1.062 \\
(0.663)^{*}\end{array}$ & $\begin{array}{c}-1.024 \\
(0.618)^{*}\end{array}$ & $\begin{array}{c}-0.871 \\
(0.522)^{*}\end{array}$ & $\begin{array}{c}-0.856 \\
(0.029)^{*}\end{array}$ & $\begin{array}{l}-1.030 \\
(0.881)\end{array}$ & $\begin{array}{l}-0.994 \\
(0.813)\end{array}$ \\
\hline $\operatorname{Adj} R^{2}$ & 0.859 & 0.859 & 0.861 & 0.862 & 0.846 & 0.845 \\
\hline
\end{tabular}

Note: Standard errors are reported in parentheses. Standard errors are robust to heteroscedasticity and autocorrelation (Arellano, 1987). $* * *, * *$ and $*$ indicate coefficient significant at the $1 \%, 5 \%$ and $10 \%$ levels, respectively. All regressions include a full set of region and year fixed effects. Each regression has 304 observations and cover the period 1980-1995. Columns (a) present the results obtained when we use the percentage of population with high school diploma and the percentage of population with university degree as measure for education, in columns (b) we report the results when the average years of schooling of population is used. 
Table 3: Fixed Effects and Trend

\begin{tabular}{|c|c|c|c|c|c|c|}
\hline & \multicolumn{2}{|c|}{ PROPERTY CRIMES } & \multicolumn{2}{|c|}{ THEFTS } & \multicolumn{2}{|c|}{ TOTAL CRIMES } \\
\hline & (a) & (b) & (a) & (b) & (a) & (b) \\
\hline High School & $\begin{array}{l}-0.1181 \\
(0.048)^{* *}\end{array}$ & $\begin{array}{l}-0.0933 \\
(0.055)^{*}\end{array}$ & $\begin{array}{l}-0.0815 \\
(0.045)^{*}\end{array}$ & $\begin{array}{c}-0.0572 \\
(0.049)\end{array}$ & $\begin{array}{c}-0.1196 \\
(0.076)\end{array}$ & $\begin{array}{l}-0.0910 \\
(0.086)\end{array}$ \\
\hline University & $\begin{array}{l}0.1729 \\
(0.265)\end{array}$ & $\begin{array}{l}0.1656 \\
(0.268)\end{array}$ & $\begin{array}{l}0.0419 \\
(0.229)\end{array}$ & $\begin{array}{l}0.0575 \\
(0.236)\end{array}$ & $\begin{array}{l}0.3993 \\
(0.445)\end{array}$ & $\begin{array}{l}0.3682 \\
(0.431)\end{array}$ \\
\hline Enrolment & $\begin{array}{c}-0.9255 \\
(0.327)^{* * *}\end{array}$ & $\begin{array}{c}-1.3300 \\
(0.514) * * *\end{array}$ & $\begin{array}{c}-0.7098 \\
(0.296)^{* *}\end{array}$ & $\begin{array}{l}-1.0780 \\
(0.433)^{* *}\end{array}$ & $\begin{array}{c}-0.9828 \\
(0.379)^{* * *}\end{array}$ & $\begin{array}{c}-1.6022 \\
(0.581)^{* * *}\end{array}$ \\
\hline Employment & $\begin{array}{c}-0.0339 \\
(0.042)\end{array}$ & $\begin{array}{c}-0.0178 \\
(0.049)\end{array}$ & $\begin{array}{c}-0.0268 \\
(0.037)\end{array}$ & $\begin{array}{c}-0.0188 \\
(0.040)\end{array}$ & $\begin{array}{c}-0.0455 \\
(0.079)\end{array}$ & $\begin{array}{c}-0.0184 \\
(0.087)\end{array}$ \\
\hline Gdp per capita & $\begin{array}{l}0.0019 \\
(0.001)^{*}\end{array}$ & $\begin{array}{l}0.0018 \\
(0.001)\end{array}$ & $\begin{array}{l}0.0019 \\
(0.001)^{*}\end{array}$ & $\begin{array}{l}0.0020 \\
(0.001)^{*}\end{array}$ & $\begin{array}{c}0.0022 \\
(0.0014)\end{array}$ & $\begin{array}{c}0.0021 \\
(0.0015)\end{array}$ \\
\hline Growth rate & $\begin{array}{c}-0.0032 \\
(0.010)\end{array}$ & $\begin{array}{l}0.0033 \\
(0.010)\end{array}$ & $\begin{array}{c}-0.0030 \\
(0.009)\end{array}$ & $\begin{array}{l}0.0016 \\
(0.009)\end{array}$ & $\begin{array}{c}-0.0035 \\
(0.013)\end{array}$ & $\begin{array}{l}0.0035 \\
(0.014)\end{array}$ \\
\hline Wage & $\begin{array}{l}-0.0018 \\
(0.001)^{*}\end{array}$ & $\begin{array}{c}-0.0010 \\
(0.001)\end{array}$ & $\begin{array}{l}-0.0010 \\
(0.0008)\end{array}$ & $\begin{array}{c}-0.0005 \\
(0.001)\end{array}$ & $\begin{array}{c}-0.0034 \\
(0.001)^{* *}\end{array}$ & $\begin{array}{c}-0.0023 \\
(0.002)\end{array}$ \\
\hline Unknown & $\begin{array}{c}0.0554 \\
(0.018)^{* * *}\end{array}$ & $\begin{array}{c}0.0539 \\
(0.019)^{* * *}\end{array}$ & $\begin{array}{c}0.0417 \\
(0.021)^{* *}\end{array}$ & $\begin{array}{c}0.0404 \\
(0.019)^{* *}\end{array}$ & $\begin{array}{l}0.0032 \\
(0.018)\end{array}$ & $\begin{array}{l}0.0034 \\
(0.019)\end{array}$ \\
\hline Police & $\begin{array}{l}3.7068 \\
(2.069)^{*}\end{array}$ & $\begin{array}{l}3.4625 \\
(2.087)^{*}\end{array}$ & $\begin{array}{c}3.0995 \\
(1.729)^{*}\end{array}$ & $\begin{array}{c}2.7608 \\
(1.690)^{*}\end{array}$ & $\begin{array}{l}4.9547 \\
(2.996) *\end{array}$ & $\begin{array}{l}4.4849 \\
(2.888)\end{array}$ \\
\hline Primo Grado & $\begin{array}{l}0.2960 \\
(0.322)\end{array}$ & $\begin{array}{l}0.2849 \\
(0.321)\end{array}$ & $\begin{array}{l}0.2588 \\
(0.253)\end{array}$ & $\begin{array}{l}0.2186 \\
(0.248)\end{array}$ & $\begin{array}{l}0.5325 \\
(0.454)\end{array}$ & $\begin{array}{l}0.5434 \\
(0.463)\end{array}$ \\
\hline Appello & $\begin{array}{l}-1.3986 \\
(0.754)^{*}\end{array}$ & $\begin{array}{l}-1.4029 \\
(0.833)^{*}\end{array}$ & $\begin{array}{c}-1.2519 \\
(0.614)^{* *}\end{array}$ & $\begin{array}{l}-1.1447 \\
(0.672)^{*}\end{array}$ & $\begin{array}{c}-1.2659 \\
(1.052)\end{array}$ & $\begin{array}{l}-1.228 \\
(1.176)\end{array}$ \\
\hline $\begin{array}{l}\text { Linear trend } \\
\text { Ouadratic trend }\end{array}$ & Yes & Yes & Yes & $\begin{array}{l}\text { Yes } \\
\text { Yes }\end{array}$ & Yes & $\begin{array}{l}\text { Yes } \\
\text { Yes }\end{array}$ \\
\hline $\operatorname{Adj} R^{2}$ & 0.875 & 0.879 & 0.875 & 0.882 & 0.864 & 0.869 \\
\hline
\end{tabular}

Note: Standard errors are reported in parentheses. Standard errors are robust to heteroscedasticity and autocorrelation (Arellano, 1987). $* * *, * *$ and $*$ indicate coefficient significant at the $1 \%, 5 \%$ and $10 \%$ levels, respectively. All regressions include a full set of region and year fixed effects. Each regression has 304 observations and cover the period 1980-1995. Columns (a) include linear region-specific time trend, while column (b) include both linear and quadratic region-specific time trend. 
Table 4: GMM-System

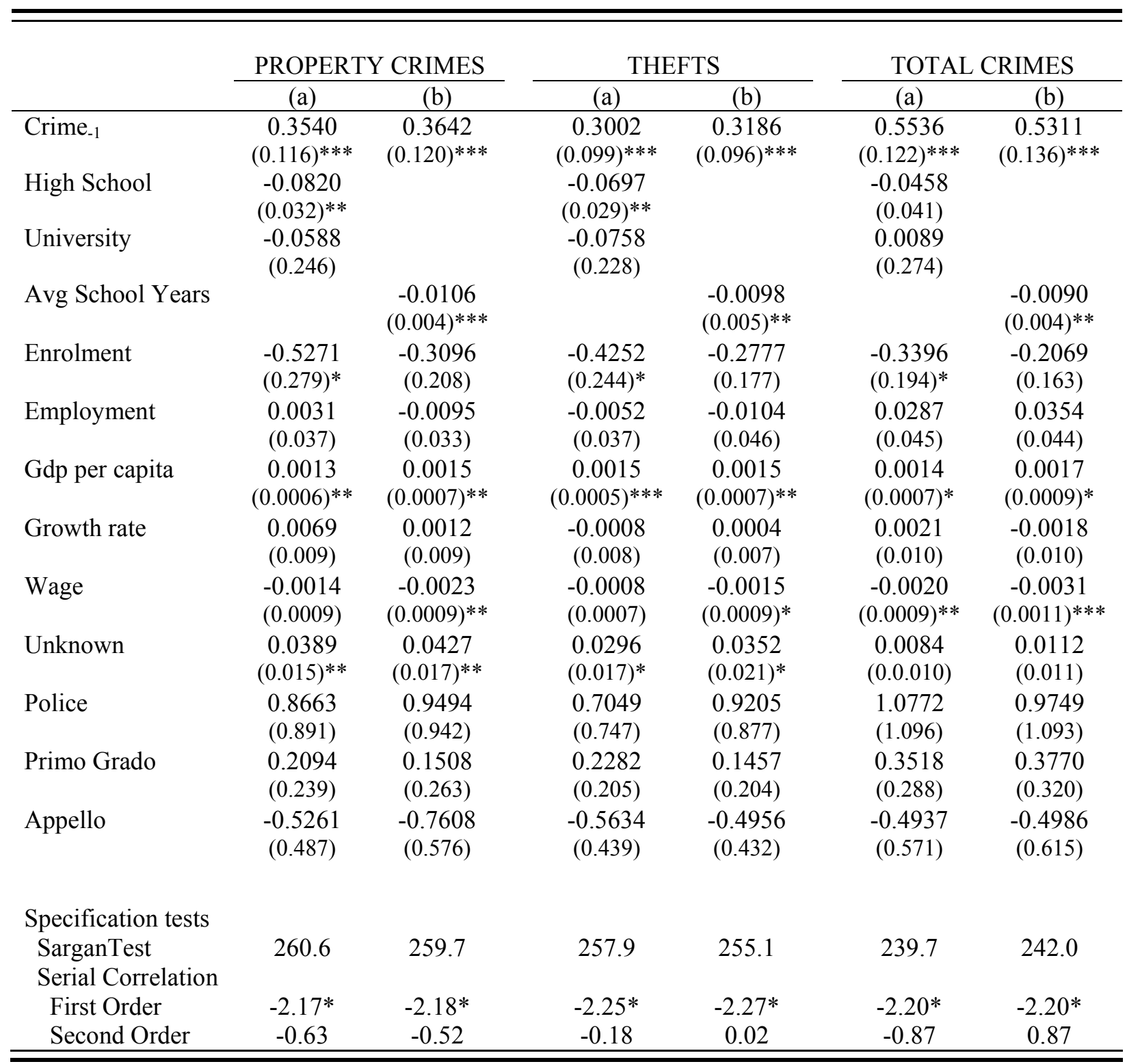

Note: First Order and Second Order Test are test statistics for first and second order autocorrelations in residuals, respectively, distributed as standard normal $\mathrm{N}(0,1)$ under the null of no serial correlation. Sargan test is a test of overidentifying restrictions, distributed as chi-square under the null of instrument validity. Standard errors are reported in parentheses. Standard errors are robust to heteroscedasticity and autocorrelation (Arellano, 1987). ***, ** and $*$ indicate coefficient significant at the $1 \%, 5 \%$ and $10 \%$ levels, respectively. All variables are instrumented using lag t-2. Each regression has 304 observations and cover the period 1980-1995. Columns (a) present the results obtained when we use the percentage of population with high school diploma and the percentage of population with university degree as measure for education, in columns (b) we report the results when the average years of schooling of population is used. 